\title{
The Railway Metropolis
}

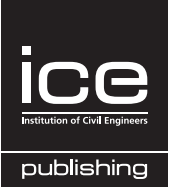


Downloaded by [] on [26/04/23]. Copyright $\odot$ ICE Publishing, all rights reserved. 


\section{The Railway Metropolis \\ How Planners, Politicians and Developers Shaped Modern London}

Michael Schabas 
Full details of ICE Publishing sales representatives and distributors can be found at www.icebookshop.com/bookshop_contact.asp

\section{Also available from ICE Publishing}

The Contractors

H. Ferguson and M. Chrimes. ISBN: 978-0-7277-5830-9

Jubilee Line Extension: From Concept to Completion

R. Mitchell. ISBN: 978-0-7277-3028-29

Transportation Engineering

J. Wright. ISBN: 978-0-7277-5973-3

\section{www.icebookshop.com}

A catalogue record for this book is available from the British Library ISBN 978-0-7277-6180-4

(C) Thomas Telford Limited 2017

ICE Publishing is a division of Thomas Telford Ltd, a wholly owned subsidiary of the Institution of Civil Engineers (ICE).

All rights, including translation, reserved. Except as permitted by the Copyright,

Designs and Patents Act 1988, no part of this publication may be reproduced, stored in a retrieval system or transmitted in any form or by any means, electronic, mechanical, photocopying or otherwise, without the prior written permission of the Publisher, ICE Publishing, One Great George Street, Westminster, London SW1P 3AA.

This book is published on the understanding that the author is solely responsible for the statements made and opinions expressed in it and that its publication does not necessarily imply that such statements and/or opinions are or reflect the views or opinions of the publishers. While every effort has been made to ensure that the statements made and the opinions expressed in this publication provide a safe and accurate guide, no liability or responsibility can be accepted in this respect by the author or publishers.

While every reasonable effort has been undertaken by the authors and the publisher to acknowledge copyright on material reproduced, if there has been an oversight please contact the publisher and we will endeavour to correct this upon a reprint. Word importing the masculine gender only shall include the feminine gender and vice versa as applicable.

Cover image: Canary Wharf Limited and Crossrail Ltd

Senior Commissioning Editor: Gavin Jamieson

Commissioning Editor: Michael Fenton

Production Editor: Rebecca Norris

Market Development Executive: Elizabeth Hobson

Designed and typeset by Kneath Associates, Swansea

Index created by Nigel d'Auvergne

Printed and bound in Great Britain by Bell + Bain Limited, Glasgow 


\section{Contents}

\section{About the Author}

A Note on Terminology and References

Glossary of Acronyms

Preface

Building a City Where the

"Rich" Use Public Transport

1 The Road Not Taken

London Says No to Sprawl and Motorways

Utopian Visions

Broken Dreams: London Underground's

"New Works"

Railway Modernisation

The Victoria Line

Motorways for London

Central London Car Policies

"Traffic Engineering" Schemes

The Victoria Line Opens

The Piccadilly Line to Heathrow

Great Northern Electrification

Jubilee Line Phase 1

The Greater London Council Takes Control

2 Mrs Thatcher's Urban Development Revolution

"Fares Fair"

Bus Privatisation

Integration and Ticketing

Electrification, Broadgate and City Thameslink

Network SouthEast

Heathrow Express: A Privately Financed Railway
3 The Tide Begins to Turn

Creating the Docklands Light Railway

Creation of the London Docklands Development Corporation

Why a "Light Railway"?

4 The Birth of Canary Wharf

The Canadians Come to London

Caveat Emptor (The Buyer Should Beware!)

A Road in Name Only

And the Riverbus?

5 Making the Toy Train into a Real Railway Fixing the DLR

Turnkey Contract to Prime Contract

Improving Reliability

Bank Station: The Neck of the Bottle

Finding a Role for Tower Gateway

Problems at North Quay Junction

Canary Wharf DLR Station: Focal Point or Folly?

Stratford and Pudding Mill Lane

Improving the Stations

6 "Take Derelict Land, Add Railway and Stir" Extending the DLR

The Lewisham Extension

City Airport and Woolwich Extensions

Lea Valley and Stratford International

Rebuilding Bank - Again

Scorecard

Was it worth it?

\section{4}

47

52

54 
Who made it happen?

Could it have been done smarter?

What could still happen?

7 From Big Bang to Big Bust

Jubilee versus Crossrail

The Art and Science of Transport Planning

The Central London Rail Study

O\&Y Gets Into the Railway Business

The Waterloo \& Greenwich Railway

The East London Rail Study

Waterloo or Charing Cross?

Southwark and Bermondsey

Leamouth or North Greenwich?

Stratford and/or Woolwich and Thamesmead

A new line or extension of an existing line?

ELRS Underlying Assumptions and Definition of

"Do Minimum"

Early Start on Preparing the Bill

The ELRS Recommendations

O\&Y Response to ELRS

JLW's “Independent Examination"

The Deal

8 Mission Creep

Building the Jubilee Line Extension

The Private Bill Process

The JLE in Parliament

Mismanagement or Mission Creep? (Why Did It End Up

Costing So Much?)

Canary Wharf Goes Into Administration

Construction and Operational Problems

The NATM Debacle

Train Control Choices

Trying to Get It Open

Scorecard

Was it worth it?

Who made it happen?

Could it have been done smarter?
9 A New Gateway to Europe St Pancras, Stratford and the Channel Rail Link

Re-Emergence of the "Commercial" Railway

Previous Tunnel Schemes

The Eurotunnel Concession

The "Slow" Link: A National Embarrassment?

The Route Shifts North

Domestic Services: Which Trains, To and From Where?

King's Cross or St Pancras?

Union Railways Plans the Route

The Stratford Box

A New Role for St Pancras

New Platforms for Thameslink

LT Northern and Western Ticket Halls

A Link to Euston?

The WCML Link

London \& Continental Railways

Scorecard

Was it worth it?

Who made it happen?

Could it have been done smarter?

What could still happen?

10 A Real "Tram" for London Croydon Tramlink

Scorecard

Was it worth it?

Could it have been done better?

Why did it happen?

11 Reform and Innovation Creating Transport for London The Transport Governance Debate The Company Plan and a "Decently Modern Metro" Privatisation, Private Finance and the PPP 
12 Low-Hanging Fruit

The London Overground

North, West and South London Lines

East London Line

Transport for London Takes Over

Scorecard

Was it worth it?

Who made it happen?

Could it have been done better?

What could still happen?

13 Crossrail

The Hare?

Origins and Objectives

1990 Crossrail Review

Evolution of the Crossrail Scheme

The Central London Route

Progress of the 1991 Crossrail Bill

Alternatives to Crossrail

Integration with Channel Tunnel Rail Link

Boom into Bust

Railtrack Tries to Take Contro

The London East-West Study

GB Railways and CR2

SuperMetro

Cross London Rail Links

London Regional Metro

Richmond and Ebbsfleet

Crossrail Business Case 2003

Montague Review 2004

Superlink

Wider Economic Benefits

The Crossrail Funding Deal

Scorecard

Is it worth it?

Who made it happen?

Could it have been done better?

What could still happen?
14 Thameslink

The Tortoise?

Is it worth it?

Endnotes

Works Cited

Index
240

Who made it happen?

Could it have been done better?

15 Looking Backwards and Forwards

London's Transport Transformed

So What Might the Next Quarter of a Century Bring?

Urban Transport: Evolution or Intelligent Design?

Acknowledgements

Picture Acknowledgements

Further Reading 


\section{About the Author}

Michael Schabas lived in London for a year as a teenager but grew up mostly in Toronto, a city with lots of cars and a small but well-used "subway". After earning degrees in Architecture (University of Toronto) and Transport Planning (Harvard Kennedy School), he worked on rail projects in Vancouver and Honolulu. He came to London in 1988 to work for the Canary Wharf developers, and was involved in promoting the Jubilee Line Extension and upgrading the Docklands Light Railway. He then worked as a consultant, advising the London Docklands Development Corporation and several east London boroughs promoting extensions to the East London Line, which eventually became a key part of the Overground. He helped residents at King's Cross fight British Rail's plans to demolish their neighbourhood to build the Channel Tunnel Rail Link (now HS1), and built the case to use St Pancras as the new terminal. He was then retained by another part of British Rail to develop the idea.In 1994, the Department of Transport retained him to review the Crossrail project, and find ways to improve access to London airports. In 1995, he founded GB Railways, winning the Anglia Railways franchise when British Rail was privatised. Over seven years, GB Railways procured $\mathcal{L}_{100}$ million worth of new trains, doubling service frequencies and passenger ridership, and eliminating the need for subsidies. It launched three new train companies - GB Railfreight, Hull Trains and Great Southern Railway (Australia) - that continue to this day, and briefly operated an experimental "London Crosslink" service between Chelmsford and Basingstoke. After GB Railways was taken over by FirstGroup plc, he returned to consulting and is now a partner of First Class Partnerships, a rail strategy consultancy advising on projects around the world. 


\section{A Note on Terminology and References}

The organisation responsible for planning and delivering London's public transport has had many names. It was the London Passenger Transport Board (1933-1948), London Transport Executive (1948-1963), London Transport Board (1963-1970), London Transport Executive (1970-1984), London Regional Transport (1984-2000) and now Transport for London (2000-). In the 1980s, London Underground Limited was established as a separate wholly owned subsidiary of LT, which it remains. To avoid confusion, I usually refer to all of these organisations as London Transport or LT, even where the actual name at the time being described was different. When writing about the organisation at central government responsible for public transport I usually refer to DfT or the Department for Transport, although the portfolio has been sometimes combined with other functions.

Many of the schemes described in this book have had more than one name. The "River Line" became the "Fleet Line" and then finally the Jubilee Line. The Channel Tunnel Rail Link is now HS1, while the East London Line became part of the "RingRail" scheme that is now known as London Overground. Shortly before publication, LT announced that Crossrail would be known as the "Elizabeth" Line. With this one exception, I use the name in use in 2016, when this book went to press, even if it was not the name at the time I am describing.

Footnotes are identified in the usual way with superscript; they provide further detail or explanation that may be of interest to some readers. Endnotes are identified with superscript italics and provide sources and references for further information. 


\section{Glossary of Acronyms}

\begin{tabular}{|c|c|c|c|}
\hline АTO & Automatic Train Operation & ELRiC & East London River Crossing \\
\hline \multirow[t]{2}{*}{ BA } & \multirow{2}{*}{$\begin{array}{l}\text { British Airways } \\
\text { (the UK airline created by merging BEA and BOAC) }\end{array}$} & ELRS & East London Rail Study \\
\hline & & EMU & Electric Multiple Unit \\
\hline BAA & British Airports Authority (and then BAA plc) & EPS & European Passenger Services \\
\hline BCV & Bakerloo Central Victoria & \multirow[t]{2}{*}{ ERTMS } & \multirow{2}{*}{$\begin{array}{l}\text { European Rail Traffic Management System } \\
\text { (a version of CBTC) }\end{array}$} \\
\hline BEA & British European Airways & & \\
\hline BNOC & British National Oil Company & ExCeL & Exhibition Centre London \\
\hline BOAC & British Overseas Airways Corporation & GE & Great Eastern \\
\hline $\mathrm{BR}$ or $\mathrm{BRB}$ & British Rail or British Railways Board & GEC & General Electric Company \\
\hline CAA & Civil Aviation Authority & GLA & Greater London Authority \\
\hline СBTC & Communications-Based Train Control & GLC & Greater London Council \\
\hline CLRL & Cross London Rail Links & HEX & Heathrow Express \\
\hline CLRS & Central London Rail Study & HFA & Halcrow Fox Associates \\
\hline CTRL & Channel Tunnel Rail Link (now HS1) & HS1 & High Speed 1 (originally the Channel Tunnel Rail Link) \\
\hline CWG & Canary Wharf Group & HS2 & High Speed 2 (proposed) \\
\hline DB & Deutsche Bahn (German railway company) & HST & High Speed Train \\
\hline DBOT & Design, Build, Operate and Transfer & IOC & International Olympic Committee \\
\hline DfT & Department for Transport & JLE & Jubilee Line Extension \\
\hline & (formerly Department of Transport, Env & JLW & James Lang Wootton \\
\hline DLR & Docklands Light Railway & JNP & Jubilee Northern Piccadilly \\
\hline ELL & East London Line & KCC & Kent County Council \\
\hline ELLG & East London Line Group & LASAS & London Airports Surface Access Study \\
\hline
\end{tabular}




\begin{tabular}{|c|c|c|c|}
\hline LCC & London County Council (predecessor to the GLC) & PFI & Private Finance Initiative \\
\hline LCR & London \& Continental Railways & PLA & Port of London Authority \\
\hline LDDC & London Docklands Development Corporation & PPP & Public Private Partnership \\
\hline LGVs & Lignes à Grande Vitesse & PSDs & Platform Screen Doors \\
\hline LOB & Location of Offices Bureau & PUG & Passenger UpGrade \\
\hline LOROL & London Overground Rail Operations Limited & RACHEL & Rail Alternative to the Channel Tunnel \\
\hline LT & London Transport & SELTrac & Standard Elektrik Lorenz Trac (a proprietary CBTC system) \\
\hline & (also London Regional Transport and TfL) & SPC & Special Purpose Company \\
\hline LT\&S & London, Tilbury \& Southend (railway line) & SRA & Strategic Rail Authority \\
\hline LTS & London Travel Study & SSL & Sub-Surface Lines \\
\hline LUL & London Underground Limited & SSRA & Shadow Strategic Rail Authority \\
\hline MBO & Management Buy-Out & $\mathbf{T} \& \mathbf{H}$ & Tottenham \& Hampstead (railway line) \\
\hline MMC & Monopolies \& Mergers Commission & T\&W Act & Transport \& Works Act \\
\hline MoD & Ministry of Defence & TALIS & Thames Alternative Link to the International Rail System \\
\hline NAO & National Audit Office & TfL & Transport for London \\
\hline NATM & New Austrian Tunnelling Method & TGV & Trains à Grande Vitesse \\
\hline NBC & National Bus Company & TOC & Train Operating Company \\
\hline NLL & North London Line & UTDC & Urban Transportation Development Corporation \\
\hline NSE & Network SouthEast (a division of BR) & UTS & Underground Ticketing System \\
\hline O\&Y & Olympia \& York (Canary Wharf) Developments Limited & W\&GR & Waterloo \& Greenwich Railway \\
\hline OPO & One-Person Operation & WEB & Wider Economic Benefit \\
\hline PAC & Public Accounts Committee & WRAtH & Western Rail Access to Heathrow \\
\hline
\end{tabular}




\section{Preface}

\section{Building a City Where the "Rich" Use Public Transport}

The story of London's development is, more than that of any other city, the story of its railways. Although many cities now boast larger populations and larger "metro" systems, no city has more railway lines, with more trains from more stations. With about 25 million people living in the London "commuter-shed", extending from the English Channel to the Midlands, the city is the world's largest and richest urban agglomeration. London also is less dependent on the automobile than any other megacity. No other city grew so large before widespread car ownership. Inner London lacks an express road system, or even the wide avenues of New York or Paris. It is a city built by merchants, not princes, with streets built for trade, not parades. So there is road capacity only for a tiny fraction of demand. It does now have an orbital motorway and a few radial trunk roads, but even these are narrower than equivalent roads in other cities. Railways, not roads, are the skeleton on which the flesh and fabric of London have grown. It is truly a place where the "rich" use public transport. In the morning commute, wealthy professionals ride alongside builders and students. During the day, trains are crowded with foreign visitors. In the early evening, it is not uncommon to see men in dinner jackets on the tube. 
Many people know that suburban growth has been strictly constrained since the 1930s by a "green belt". The central London Congestion Charge, introduced in 2003, is known around the world, although few cities have copied it, and the impact has, in fact, been limited. Less widely known is that developers have been forbidden from building car parks in central London since the 1960s. British taxes on car ownership and use are among the highest in the world.

Green belt policy has had an enormous and unintended impact on the housing market, restraining new construction and ultimately, by the end of the century, causing severe house price inflation. But it has also helped the viability of passenger railways. Commuters, rich and poor, take the tube, bus, or bicycle to work in central London. About half a million people now travel every day into central London from the "Home Counties", towns in and beyond the green belt. Planning policies have forced homes to be built close to existing towns, and thus with convenient access to rail stations. One unintended consequence of green belt policy is that commuting distances are relatively long, and distance favours rail over road.

Despite - or perhaps because of - such restrictive policies, London has retained and strengthened its position as the leading "world city", pre-

eminent in finance, medicine, education, art, entertainment, publishing, and many other sectors. Its continued growth and prosperity have only been possible because the railways have also been improved and expanded. The costs have been huge, but so have the benefits.

Railways can be designed well or badly. Engineers, planners, operators, property developers and politicians make decisions that shape the city for centuries to come. Mistakes that are made in a moment can affect travellers for decades or centuries. Sometimes they are the result of conscious action, which may be recognised later as brilliant foresight or an expensive mistake. More often, opportunities are simply missed, just failures of vision. Some errors are never even recognised as such; the operators who inherit the system assume there must have been a good reason it was done "this way". Stations can be beautiful yet poorly located (or even entirely unnecessary) Railway lines can be fast but circuitously routed. Passengers never know that their trip is longer, less convenient, or their taxes higher, because of somebody's blunder half a century ago. Engineering and planning decisions can add massively to costs, often with little or no benefit. Sometimes, a cheaper solution would even have offered a better solution. Railways are an industry where the "production line" is visible for all to see, yet operational shortcomings are often less than obvious and even counter-intuitive to the politicians who approve them and the engineers who build them. Too often, railway builders have repeated mistakes of previous generations.

To build better for the future, you need to understand the past. Railways are unlike other infrastructures, such as communication cables, water pipes and power lines. They cannot be easily abandoned or replaced. Old railways occupy valuable space but also provide irreplaceable corridors that can be reused. Once built, railways are hard to change, because thousands of passengers come to depend on them. Whereas car traffic can "find its own level", spreading across a network and using additional capacity as it is created, rail track capacity is only useful if trains operate on it. Cars can usually transfer between local roads, expressways and motorways fairly easily. Railway technology can be more efficient, but it is also less flexible. Roads can be upgraded incrementally, but rail investment usually requires coordinated changes to track, signalling and rolling stock. Rail interchanges can be easy, or difficult, depending on the cleverness of the designers and topographic circumstances. Lines may cross on a map, but unless there is an interchange station passengers cannot travel between them. A junction or curve may become a permanent speed and capacity constraint. Once built, it may be impractical to ever change it.

Many books have been written about London's railways. Popular histories describe the promotion and development of the earliest lines, rich with anecdotes of struggles between heroic engineers and less scrupulous politicians and financiers. Lavishly illustrated books are published about the design and architecture, the stations and trains and even the iconic tube map. Technical tomes examine specific aspects of the planning or engineering. There are many books directed at railway "enthusiasts", presenting encyclopaedic detail about trains and stations, but often little discussion of why any of this really matters. General histories of London and its development touch on issues of politics and finance, and mention rail projects and their impacts. While they describe what was built, they rarely explain why. They usually do not discuss the routes and technology choices that were considered, why a specific solution was adopted, and whether it was, in retrospect, the right choice.

As government and technology have become more complex, planning and design of network improvements have come under the de facto contro of technocrats, who make decisions as to the schemes that should be studied and promoted. But if there are fewer villains, there are also fewer heroes. While the decision as to whether a scheme should be funded and proceed is made by elected politicians, they do not always have the time or inclination to understand all implications of the choices. Expensive mistakes are made, and valuable opportunities are missed.

Details of planning, technology choice, design and funding of the railway projects, are usually not well documented, and often misunderstood or intentionally obfuscated. Transport planners tend to use "black box" computer models to support their recommendations, and often the scheme that ranks best in the model only does so because of an obscure or implicit assumption that has never been debated and mav even be wrong. Engineering issues are complex, crossing several disciplines, and often not even well understood by the so-called experts. Funding arrangements are opaque, and even commercially confidential. Inflation makes it difficult to evaluate historic costs, while traffic forecasts are based on assumptions that rarely correspond to the outcome.

A few organisations, such as London Transport and the London Docklands Development Corporation, have produced semi-official histories of specific projects. While rich in detail, these usually avoid critical analysis as to whether schemes delivered as promised, and they rarely speculate as to what might have happened if different choices had been made. There 


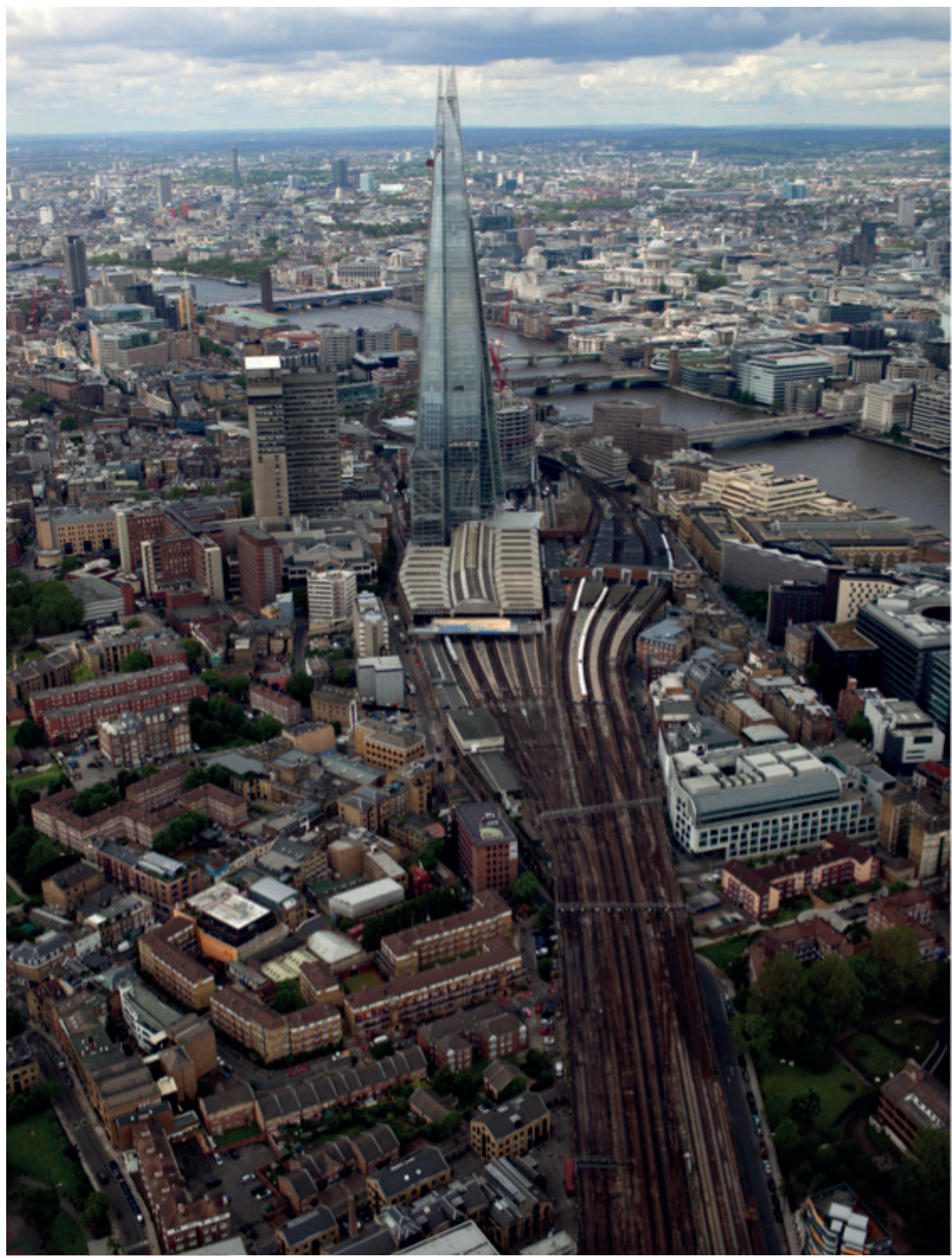

is sometimes reference to cost-benefit analysis, although usually without much explanation or understanding of how or why it is used, and what it tells us.

This book is about how London turned its aging and often rundown railways into the best system in the world. There is a chapter on each of the lines that have been added since 1980, explaining why each was built, whether it has proved worthwhile, and whether it could have been done better. I tell how planners, politicians and developers decided what railways to build, where to build them, and how to fund and operate them. It is a story of successes and failures, bold and brilliant strategies, bumbling mistakes and expensive "white elephants". The railway infrastructure takes centre stage, but I also consider changing operating practices, fares and management that have been critical to the transformation of the metropolis's transport system.

I have tried to focus on the design and planning decisions that can have wider lessons for planners and policymakers. Readers seeking comprehensive historical or technical detail on specific projects should refer to the source materials.

The network continues to grow, and investment has even accelerated in the last decade. My hope is that, by telling the stories of why it was done the way it was done, and the result, we might learn how to do it better.

I draw on public and private documents, archives, recollections and recent interviews with more than fifty people who were involved in one way or another in the development of modern London's railways. The time period covered is, more or less, from the election of the Thatcher government and the resurgence of London as a World City through to the present day. I worked in some way on most of the rail projects in this period, although not usually within the project "establishment". I had contact with most of the key decision makers. Sometimes I was able to make constructive input; more often I was just close enough to see the implications, good and bad, of the decisions that were made by others.

Many of the key decision shapers are now retired. Among those who are still active, memories are fading. If the history of London's railways during this important period is to be written, now is the time. Long enough has passed that people have been able to speak fairly freely about the guilty as well as the heroes. And people (including the author) have come to accept and even regret some of the mistakes they have made, while also celebrating the many successes. I have not concealed where I had personal involvement, but I have avoided making this a memoir.

The story of London's railways since 1945 is one of innovative planning (both of the "city" and the "transport" variety), but with plans rarely implemented as originally envisaged. New technology, and new funding and delivery structures, have been adopted with varying degrees of success, often because policy makers (both elected and unelected) have not fully understood the choices and their implications.

In the late 1940s, post-war optimism produced a wave of expensive and impractical schemes. Reality soon set in and the mood switched to 
austerity. Prosperity returned in the 1960s, 1980s, and 2000s, interrupted by gloomy recessions. In each boom, old rail schemes were revived and hurriedly reviewed, with a few proceeding to implementation, sometimes but not always adapted to new and changing needs and opportunities. At each stage, planners tried to devise solutions that would solve the problems left from the past and address the needs they saw in the future. Politicians struggled to find the money, not just to expand the system but often just to keep the existing lines running and in reasonable repair. Sometimes failures in planning and politics resulted in "white elephants" - railways built at great expense that obviously did not deliver commensurate benefits. More often, compromises were reached or schemes salvaged to deliver acceptable solutions, albeit perhaps not the best that would have been possible if all parties had understood all the opportunities. In some cases, succes ultimately surpassed expectations.

While London newspapers regularly complain of a failure to "invest in infrastructure", the actual expenditure in rail has been enormous. Three large and essentially new railways have been built since 1980: the Docklands Light Railway, the Jubilee Line Extension and High Speed 1. A fourth, Crossrail, is nearing completion. Each of these is a multi-billion pound project. Two other projects, London Overground and Thameslink, run mostly over infrastructure dating from the 19th century, but have involved short sections of new construction and reconfiguration of services with a scale and cost that makes them comparable to new lines. Several smaller rail schemes have been developed to serve London's airports. Various other parts of the suburban rail network have been reconfigured, most notably aroun Croydon where extensive light rail Tramlink has been developed. Billions more have been spent re-equipping and rebuilding the 40-plus existing rail lines that serve the London metropolis, greatly expanding the capacity and reach of the network. These schemes have mostly been developed incrementally, less because of a failure to plan at all but more in response to changing, unexpected and perhaps fundamentally unpredictable new opportunities.

In comparison with, say, France, Britain is sometimes not thought to be very good at "big projects". But the results would suggest that this is not perhaps such a bad thing: rail transport in London is as extensive, effective and efficient as in any megacity. Although Victorian origins are often still visible, London truly now has a modern rail system. Looking back, the first four decades of the century, up to 1939, were the "Golden Age" of London Transport. The nascent tube network was integrated and extended across the metropolis. In contrast, the four decades after the war were, in many ways, a period of managed decline. There was sporadic investment, but in the context of rising costs and declining ridership. But it was also a period of adjustment, when planners, railway operators and politicians learned to manage and ultimately compete with the automobile, and to address other technological and social changes that dramatically affected the environment in which railways operated. This is the subject of the next chapter.
The Railway Metropolis -

Opposite - The ten-track rail corridor into London Bridge is one of the busiest in the world. This photo from around 2013 was taken after completion of the 95-storey "Shard" tower, but before reconfiguration of the tracks and rebuilding of the station for the Thameslink project, as described in Chapter 14 
Downloaded by [] on [26/04/23]. Copyright @ ICE Publishing, all rights reserved. 


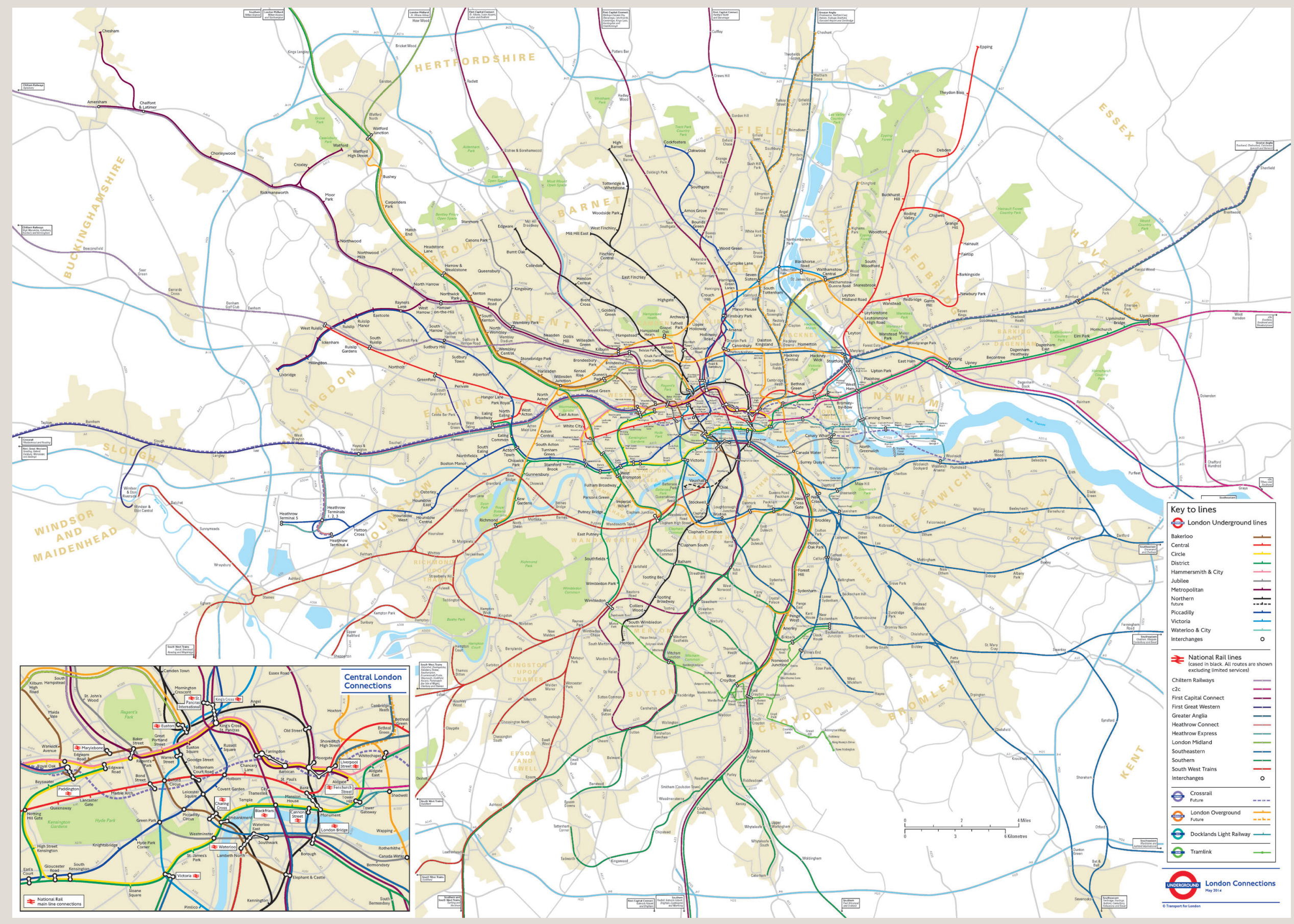

